\title{
Was meinem Auge diese Kraft gegeben
}

Johann Gottlieb Fichte

Tradutor: Paulo R. Licht dos Santos

\section{OpenEdition \\ Journals}

\section{Edição electrónica}

URL: http://journals.openedition.org/ref/532

DOI: 10.4000/ref.532

ISSN: 2258-014X

\section{Editora}

EuroPhilosophie Editions

\section{Refêrencia eletrónica}

Johann Gottlieb Fichte, "Was meinem Auge diese Kraft gegeben », Revista de Estud(i)os sobre Fichte [Online], 8 | 2014, posto online no dia 21 setembro 2014, consultado o 08 setembro 2020. URL : http:// journals.openedition.org/ref/532 ; DOI : https://doi.org/10.4000/ref.532 


\section{Johann Gottlieb Fichte}

\section{Was meinem Auge diese Kraft gegeben}

Was meinem Auge diese Kraft gegeben, Daß alle Mißgestalt ihm ist zerronnen, Dass ihm die Nächte werden heitre Sonnen, Unordnung Ordnung, und Verwesung Leben? -

Was durch der Zeit des Rams verworrnes Weben Mich sicher leitet hin zum ew'gen Bronnen, Des Wahren, Guten, Schönen und der Wonnen Und ihm vernichtend eintaucht all mein Streben?

Das ist's: seit in Uraniens Auge die tiefe Sich selber klare, blaue, stille, reine Lichtflamm', ich selber still, hineingesehen;

Seitdem blieb dieses Aug' mir in der Tiefe, Und ist in meinem Sein - das ewig Eine Lebt mir im Leben, sieht in meinem Sehen.
Que me teria dado ao olhar um tal poder, Que tudo o que é disforme a nada enfim reduz, Que as noites transfigura em sóis de clara luz, Desordem em ordem torna e perecer viver?

Que, pelo espaço e tempo enleados no tecer, Ali, à fonte eterna a salvo me conduz, Fonte que o Belo, Vero, Bem, Prazer produz, Na qual desfeito inteiro imerge o meu querer?

É isto: foi por ter eu quieto adentro olhado No olhar de Urânia a flama-luz a si incender Profunda e azul e quieta em pura claridade

É assim que tal olhar profundo em mim pousado Reside e em meu Ser é. E assim vê no meu ver, Vive no meu viver - a eterna Unidade.

\section{Para citar este artículo}

Referencia electrónica

Johann Gottlieb Fichte, «Was meinem Auge diese Kraft gegeben », Revista de Estud(i)os sobre Fichte [En línea], 8 | 2014, Publicado el 21 septiembre 2014, consultado el 12 marzo 2015. URL : http:// ref.revues.org/532

\section{Derechos de autor}

(C) EuroPhilosophie

\section{Notas de la redacción}

Este soneto ha sido publicado originalmente en P. R. LICHT DOS SANTOS, "Dois poemas e quatro exposições: J. G. Fichte e H. M. Enzensberger”, CADERNOS DE FILOSOFIA ALEMÃ, 10 (Jul.-Dez. 2007) 101-114 